DOI https://doi.org/10.18551/rjoas.2018-09.42

\title{
COMPETENCY DEVELOPMENT MODEL FOR ENGLISH LANGUAGE LECTURER IN THE INDONESIAN NAVAL ACADEMY
}

\author{
Indriatmoko Andyseno \\ Department of Human Resource Development Program, University of Airlangga, Indonesia \\ E-mail: andyseno28@gmail.com
}

\begin{abstract}
This research focused on one component, namely lecturer especially English language lecturer in the Indonesian Naval Academy who are at the forefront in determining the quality of education in order to create qualified Indonesian Navy Academy cadets as candidates for professional Navy Officers. The purpose of this research was to determine the competence of English language lecturer in the Indonesian Naval Academy and to plan the competency development model for English language lecturer in the Indonesian Naval Academy which is ideal for the world class Naval Academy. This research was a qualitative descriptive research with data collection methods through observation, interviews and documentation. Primary data were obtained through interviews with key informant Head of Lecturer Department and follow-up informants, namely Head of Science and Technology Department, 8 English Language lecturers, as well as 40 second grader and third grader Indonesian Naval Academy cadets. Based on the results of the analysis and discussion, the following conclusions can be drawn: in the professional aspect, there are gaps related to the education level of gadik lecturers who are still dominated by Bachelor degree education, from 8 English language lecturer, there are 3 people with Master degree education, and 5 people still have Bachelor degree education; in the pedagogic aspect in classroom management indicators and learning states that the lecturers stated that they realized that they were constrained by the use of teaching methods in the classroom to be more varied because they were faced with cadets who were physically exhausted in class so that cadets were always constrained by learning by holding drowsiness; in the personality aspect, in general all lecturers' personalities in the Indonesian Naval Academy do not have a fundamental problem, they have carried out their functions as a sympathetic, authoritative, empathetic and able to share the knowledge of giving teaching to cadets as well; on the social aspect, in general, English language lecturers at the Indonesian Naval Academy also did not find significant obstacles, in their social life; the English language lecturer competency development model in the Indonesian Naval Academy begins with an inventory of competency data of English language lecturer by Lecturer Department, then competency development is directed to achieve minimum competency in each of its competencies and then being developed again in the advanced stages to improve the professionalism of English language lecturer in the Indonesian Naval Academy.
\end{abstract}

\section{KEY WORDS}

Model, development, competency, lecturer, English, cadet.

Within the scope of the organization, Human Resources is a requirement in an organization. Competent human resources will always be the key to the success of achieving organizational goals. The Indonesian Navy as a national defense organization with a very important and complex task is supported by two main pillars. The first pillar is human resources and the second pillar is the main weaponry system. Both pillars must always be developed to be better in order to achieve dreams in the framework of the World Class Navy that is able to contribute in the military and non-military fields where not only local / national scale but also the global scale so that it is worthy of being equal with the developed countries Navy in this world. The New World Class Navy's New Paradigm was responded positively by the Indonesian Naval Academy by supporting the paradigm and following up by building a World Class Naval Academy, so as to be able to have equality with the Naval Academy 
owned by developed countries in the world. In building the World Class Naval Academy, there are several components that must be considered, one of which is lecturer. This study focuses on one component, namely lecturer especially English Language lecturer in Indonesian Naval Academy who is at the forefront in determining the quality of education in order to create qualified Indonesian Naval Academy cadets as professional Navy Officer candidates. The purpose of this study was to determine the competence of English language lecturer at Indonesian Naval Academy and to plan the competency development model for English language lecturer at Indonesian Naval Academy which is ideal for the world class Naval Academy.

\section{LITERATURE REVIEW}

According to Muniarti and Isman (2009: 188) the model is a study carried out by gathering the advantages obtained and avoiding the weaknesses of the model that has been applied previously. While Masdar and Irianto (2009: 193) define the model as a mindset that is used to guide a particular activity. Then the model according to Simarmata (1983: 1) is defined as abstraction from reality by focusing only on some parts or characteristics of real life. Simarmata divides models based on functions, namely:

a. Descriptive model, which is a model that only describes the situation of a system without recommendations and forecasting as a miniature of the object being studied.

b. Predictive model, which is a model that describes what will happen when something happens.

c. The normative model, which is a model that provides the best answer to a problem. This model recommends actions that need to be taken. Also called a simulative model. The problem of normative models is usually the discovery of values from variables that can be controlled so that they will produce large benefits as measured by variations in results or criteria.

According to Spencer and Spencer (1993: 9) Competence is a characteristic that underlies a person and is related to the effectiveness of individual performance in his work (an individual characteristic that is causally related to criterion - referenced effective and superior performance in a job or situation). Underlying Characteristics means that competence is part of a deep personality and attached to a person and behavior that can be predicted in a variety of work conditions and tasks. Causally Related means that competence is something that causes or predicts behavior and performance. Criterion Referenced means that competency actually predicts who performs well, measured by the criteria or standards used.

Hornby (1982: 172) defines competence as person having ability, power, authority, skill, knowledge to do what is needed. Starting from this understanding, competence can be given meaning, people who have the ability, power, authority, skills, knowledge needed to perform a particular task.

In the Law of the Republic of Indonesia Number 14 / 2005 concerning Teacher and Lecturer explained that the competence of teacher or lecturer is a set of knowledge, skills and behaviors that must be possessed, lived, and mastered by the teacher or lecturer in carrying out professional tasks.

According to Atwi Suparman (2005), a lecturer should have three competencies, namely mastery of the field of science, curriculum skills and pedagogical skills (learning and developing ways to respond to the understanding of teaching material).

Now the dimensions of the competence of teachers and lecturers can be said to have been completed because In the Law of the Republic of Indonesia Number 14 / 2005 concerning Teacher and Lecturer explained that there are 4 dimensions of competence, namely: professional competence, pedagogic competence, personal competence and social competence.

According to Hasibuan (2001: 68) Development is an effort to improve the technical, theoretical, conceptual and moral capabilities of employees in accordance with the needs of work / occupation through education and training. Then according to Drs. Jan Bella in 
Hasibuan (2001: 69) suggests that education and training are the same as development which is a process of improving both technical and managerial work skills. Education is theory oriented, is done in class, lasts a long time and usually answers why. Practiceoriented training, carried out in the field, is short and usually answers how. Then based on the Chief of Indonesian Navy Regulations Number Perkasal / 1 / I / 2011 concerning Guidance for the Development of Lecturer Personnel, it was stated that the development of the competence of the Indonesian Navy Lecturer was carried out through education and training of Lecturer. Education and training of the Indonesian Navy Lecturer is all planned, directed and continuing efforts, work and activities to shape and develop the quality of prospective lecturer and lecturer who have the spirit of Pancasila and Sapta Marga, have personality, intelligence, skills and physical acceptance, to be able to carry out tasks.

\section{METHODS OF RESEARCH}

This research was a qualitative descriptive research with data collection methods through observation, interviews and documentation. The location of this research at the Indonesian Naval Academy. Primary data were obtained through interviews with key informant Head of Lecturer Department and follow-up informants, namely Head of Science and Technology Department, 8 English Language lecturers, as well as 40 second grader and third grader Indonesian Naval Academy cadets. The research framework is presented in Figure 1.

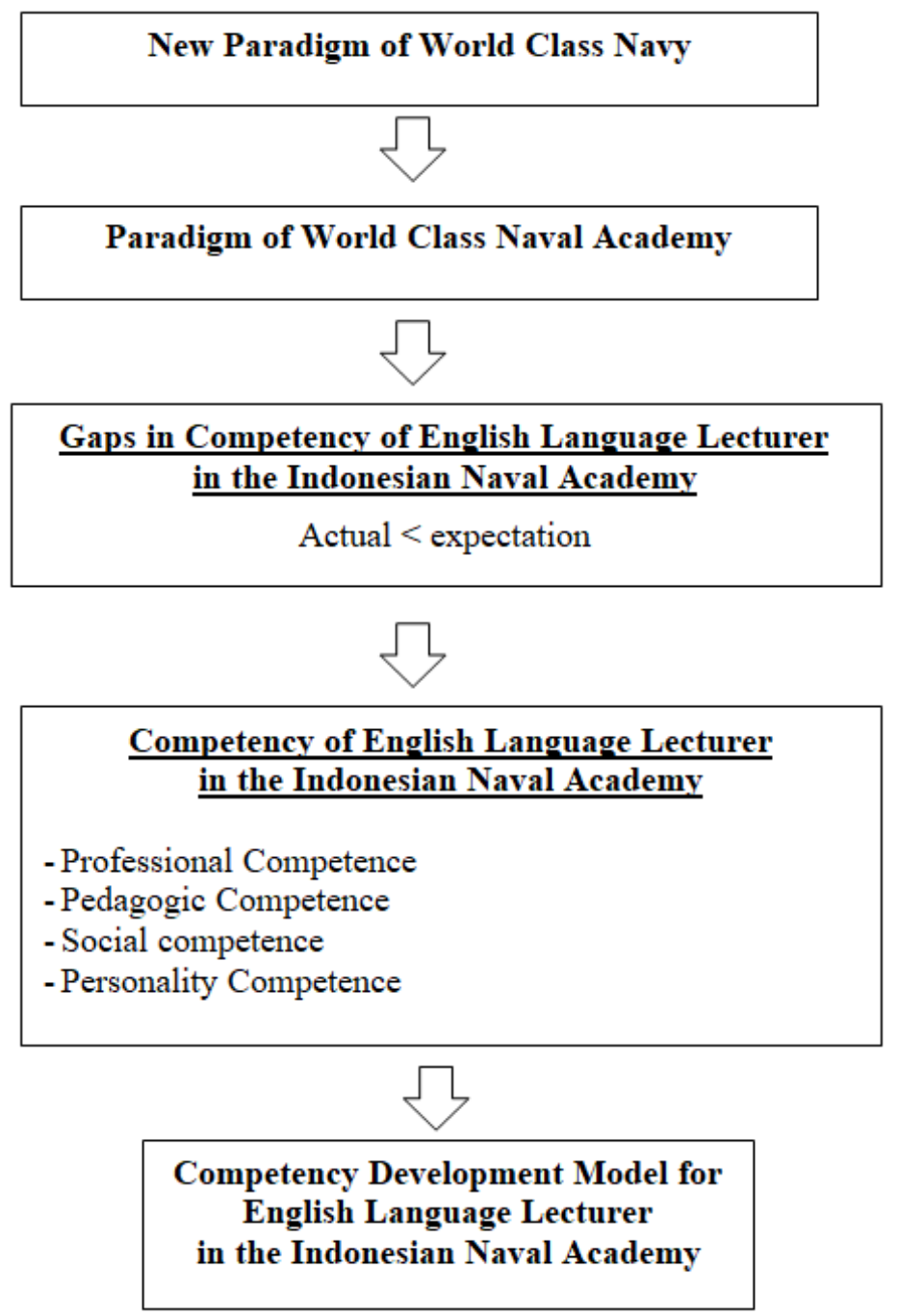

Figure 1 - Research Framework 


\section{RESULTS AND DISCUSSION}

This research was conducted at the Indonesian Naval Academy which is located at Bumimoro, Surabaya, East Java. This research was carried out in June-July 2018. Primary data were obtained through interviews with key informant Head of Lecturer Department and follow-up informants, namely Head of Science and Technology Department, 8 English Language lecturers, as well as 40 second grader and third grader Indonesian Naval Academy cadets.

From the description of the interview addressed to English language lecturers there are several points that can be highlighted, in which the real practice of the field must be addressed immediately. First, there are some lecturers who do not meet the qualifications, this is something substantial because it should be in accordance with the Law (UURI) No. 14 / 2005 requires that university lecturers have at least S2 (Master Degree). In the law mentioned, educators at the primary and secondary education levels are the minimum requirements for an S1 (Bachelor degree). Meanwhile, to educate at the S1 (Bachelor degree) academic level, at least a S2 (Master Degree), while for postgraduate programs are doctoral (S3) and professors. In addition, the competencies that must be possessed and developed by the lecturer include; pedagogic competence, social competence, personality competence and professional competence through the implementation of research, learning, community service and the preservation of moral values

Second, English language lecturers have problems with involvement in scientific activities, based on the results of the interview showed that the involvement of English language lectures in scientific activities of professional organizations is very low, from 8 lecturers interviewed, 7 said they did not participate in any professional organization, while 1 the lecturer stated that he still attended several scientific activities of professional organizations. The scientific forum is a demand and need for every lecturer to update information and gain new experience. Through scientific forums will be presented and examined various problems, root problems, positions, and problem-solving strategies from various perspectives. Activities in scientific forums are carried out in a programmed, directed and sustainable manner, not only to stop at the presentation or study, but to the level of design, development, implementation and impact assessment. By participating in a variety of scientific and scientific forums that are always up to date, this will make the lecturers have many references and variations to teach and improve the quality of cadets. The lack of lecturer involvement in scientific activities actually has its own impact, where the use of the most recent research results is rarely done, even though it is able to improve the quality of lectures.

Third, the low level of scientific publication activities, even though this activity has a very strategic role for lecturers in socializing their abilities, experiences, skills and work scientifically. The ability and willingness of lecturers to publish their work must always be developed as a form of responsibility in carrying out their main tasks. Scientific publications can be carried out through various forms of activities, such as; presentation in scientific forums, dissemination of research results, writing of scientific articles, writing of journal articles, scientific magazines, writing of books, dictates, writing in the mass media, uploading on the internet, and so on. The more scientific publications that are presented to the public, will give a positive image to the lecturers concerned as professional lecturers. To increase the number and quality of scientific publications, it is necessary to form a forum or scientific institution that is responsible for program assessment, model development, cooperation networks (partners), scientific publications carried out in a programmed, periodic, directed and sustainable manner.

Based on the results of the interview, there are several points that can be highlighted: 1). In the professional aspect, there are gaps related to the education level of gadik lecturers who are still dominated by Bachelor degree education, from 8 English language lecturer, there are 3 people with Master degree education, and 5 people still have Bachelor degree education, 2). In the pedagogic aspect in classroom management indicators and learning states that the lecturers stated that they realized that they were constrained by the use of 
teaching methods in the classroom to be more varied because they were faced with cadets who were physically exhausted in class so that cadets were always constrained by learning by holding drowsiness, 3) In the personality aspect, in general all lecturers' personalities in the Indonesian Naval Academy do not have a fundamental problem, they have carried out their functions as a sympathetic, authoritative, empathetic and able to share the knowledge of giving teaching to cadets as well, 4). On the social aspect, in general, English language lecturers at the Indonesian Naval Academy also did not find significant obstacles, in their social life.

After knowing the real conditions of the field and the weaknesses and competency development needs of the lecturers, the design model for the development of professional lecturers' competencies is tailored to the needs of lecturers using depth interview interviews. So that from the results of interviews that have been tabulated and carried out the graph, the competency development model is made as follows:

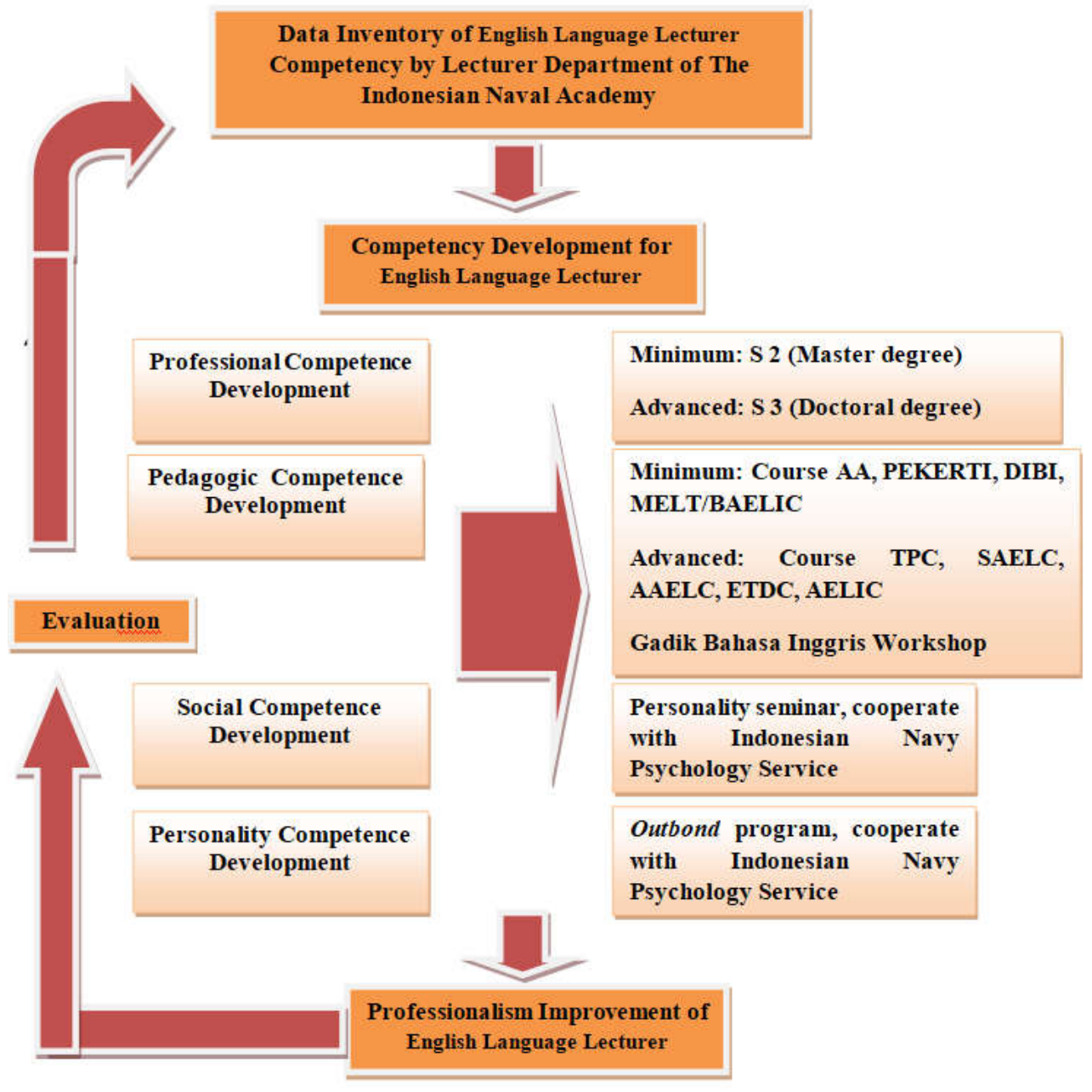

Figure 1 - Competency Development Model

\section{CONCLUSION}

Based on the results of the analysis and discussion, the following conclusions can be drawn: 1). In the professional aspect, there are gaps related to the education level of gadik lecturers who are still dominated by Bachelor degree education, from 8 English language lecturer, there are 3 people with Master degree education, and 5 people still have Bachelor degree education, 2). In the pedagogic aspect in classroom management indicators and learning states that the lecturers stated that they realized that they were constrained by the use of teaching methods in the classroom to be more varied because they were faced with 
cadets who were physically exhausted in class so that cadets were always constrained by learning by holding drowsiness, 3) In the personality aspect, in general all lecturers' personalities in the Indonesian Naval Academy do not have a fundamental problem, they have carried out their functions as a sympathetic, authoritative, empathetic and able to share the knowledge of giving teaching to cadets as well, 4). On the social aspect, in general, English language lecturers at the Indonesian Naval Academy also did not find significant obstacles, in their social life, 5). The English language lecturer competency development model in the Indonesian Naval Academy begins with an inventory of competency data of English language lecturer by Lecturer Department, then competency development is directed to achieve minimum competency in each of its competencies and then being developed again in the advanced stages to improve the professionalism of English language lecturer in the Indonesian Naval Academy.

\section{REFERENCES}

1. Taufiq R. 2014. Akademi TNI Angkatan Laut Kelas Dunia. Surabaya: AAL

2. Amirin, Tatang. Drs. 1984. Pokok-Pokok Teori Sistem. Jakarta: CV. Rajawali.

3. Arikunto. S. 1996. Dasar-Dasar Evaluasi Pendidikan. Jakarta: PT. Bumi Aksara

4. Suparman. M. 2005. Mengajar di Perguruan Tinggi. Jakarta: PAU-PPAIUT

5. Creswell, W, John, 2016. Research Desain: Pendekatan Kualitatif, Kuantitatif, dan Mixed, Yogyakarta: Pustaka Pelajar.

6. Djamarah, S.B. 2007. Guru dan Anak Didik dalam Interaksi Edukatif. Jakarta: Rineka Cipta.

7. Hari Suderadjat. 2004. Implementasi Kurikulum Berbasis Kompetensi (KBK):Pembaharuan Pendidikan dalam Undang-Undang Sisdiknas 2003. Bandung: CV Cipta Cekas Grafika.

8. Hasibuan, M.S.P. 2001. Manajemen Sumber Daya Manusia. Jakarta: PT. Bumi Aksara.

9. Herdiansyah, Haris. 2010, Metodologi Penelitian Kualitatif Untuk IImu-IImu sosial. Jakarta: Salemba Humanika.

10. Masdar, S., dkk. 2009. Manajemen Sumber Daya Manusia Berbasis Kompetensi Untuk Pelayanan Publik. Surabaya: Airlangga University Press.

11. Moleong, L.J. 2006. Metodologi Penelitian Kualitatif. Edisi Revisi. Bandung: PT Remaja Rosdakarya.

12. Mulyasa, E. 2013. Standar Kompetensi dan Sertifikasi Guru. Bandung: PT Remaja Rosdakarya.

13. Muniarti \& Isman, Nasir. 2009. Implementasi manajemen Strategik dalam Pemberdayaan Sekolah Menemgah Kejuruan. Bandung: Cipta Pustaka Media Perintis.

14. Pasolong, H. 2013. Metode Penelitian Administrasi Publik, Bandung: PT Remaja Rosdakarya.

15. Rachmawati. 2013, Kompetensi Pedagogik Guru Bahasa Inggris Bersertifikat Pendidik di SMA Negeri 1 Kolaka, Program Pasca Sarjana Prodi Manajemen Pendidikan, Universitas Muhamadiyah Surakarta, Surakarta

16. Ratminingsih, Ni Made. 2012, Profil Profesionalisme Dosen Jurusan Pendidikan Bahasa Inggris, Jurnal Pendidikan dan pengajaran, Jilid 48, Nomor 1-3, April 2015, Universitas Pendidikan Ganesha, Singaraja

17. Simarmata, Dj. A. 1983, Operation Research: Sebuah Pengantar. Jakarta: PT. Gramedia

18. Spencer, Lyle, Jr., M, and Spencer, Singe, M.. 1993. Competence At Work, John Wiley \& Sons Inc.: Kanada.

19. Sugiyono. 2016. Metode Penelitian Pendidikan: Pendekatan Kuantitatif, Kualitatif dan R \& D. Bandung: Penerbit Alfabeta.

20. Undang-undang Republik Indonesia Nomor 14 Tahun 2005 tentang Guru dan Dosen

21. Undang-undang Republik Indonesia No. 34 Tahun 2004 tentang TNI

22. Peraturan Kasal, Petunjuk Teknik Pembinaan Tenaga Pendidik, Nomor Perkasal/1/l/2011, Jakarta: 09 Januari 2011. 